\title{
THE EFFECT OF SOCIAL CAPITAL AND ORGANIZATIONAL COMMITMENT TOWARD LECTURER PERFORMANCE WITH ISLAMIC WORK ETHICS AS A MODERATING ROLE
}

\author{
Pardiman *)
}

\begin{abstract}
The number of private Islamic higher educations (PTIS) in Indonesia today amounted to 631 institutions. This condition has a tremendous potential in order to build the civilization of the Indonesian nation as aspired by Islam which is to be a nation that baldatun thoyyibatun wa rabbun ghaffur, a nation with a peace, the savety, and prosperity. The purpose of this study is to examine the impact of Islamic work ethic as moderating role on the influence of social capital and organizational commitment to the performance of lecturers. Researcher is using random sampling technique. The data collected from 236 respondents in PTIS that classified as "A" accredited by BANPT. Researcher analyzes the data collected by using WarlpPls 5.0. This research concluded that the social capital and organizational commitment has a positive effect on lecturer's performance, Islamic work ethics reinforces these influences. However, the decision of researcher in choosing only "A" accredited PTIS as his research object make this study can't be generalize.
\end{abstract}

Keywords: Social Capital, Organizational Commitment, Lecturer Performance, Islamic Work Ethics

\section{INTRODUCTION}

\subsection{Research Background}

Individual performance has become a research topic favourite by many scientists or researchers, given that performance is a measure of organization or company success. This is not too much because the accumulation of individual performance will shape the performance of the organization or company, so the better the individual performance, the better the performance of the organization (Dessler 2009). Research that examines the factors that influencing individual performance has been exposed to many variables, both intrinsic factors such as civic behavior or organizational citizenship behavior (Memari, Mahdieh, \& Marnani, 2013; Cho \& Johanson, 2008; Harwiki, 2016), organizational commitment (Khan, Ziauddin, \& Ramay, 2010; Hayati \& Caniago 2012; Jaramillo, Mulki, \& Marshall, 2005; Meyer, Paunonen, Gellatly, Goffin, \& Jackson, 1989), Work Ethics (Imam, Abbasi, \& Muneer, 2013; Abbasi, Mir, \& Hussain, 2012; Bozkurt, Bayram, Furnham, \& Dawes, 2010) as well as employee extrinsic factors such as: award (Güngör, 2011), leadership (Chen, Eberly, Chiang, Farh, \& Cheng, 2014; Wong \& Laschinger, 2013; Walumbwa, Mayer, Wang, Wang, Workman, \& Christensen, 2011; Huey Yiing \& Zaman Bin Ahmad 2009; de Araújo \& Lopes 2014; Braun, Peus, Weisweiler, \& Frey, 2013) and some more other studies. However, if we viewed from research subjects, the majority of individual performance studies involving company employees which have profit oriented as research subjects. This means that for research subjects stating in non profit oriented organizations, especially lecturers at higher education institutions in Private Islamic Higher Education (PTIS), has not been done. The number of PTIS in Indonesia today amounted to 631 institutions, 53\% are in Java, and the rest are spread in some provinces in Indonesia. In general, PTIS in Indonesia is affiliated with religious organizations, such as Nahdlatul Ulama (NU), Muhammadiyah, or other religious organizations. The condition is a tremendous potential in order to build the civilization of the Indonesian nation as aspired by Islam to be a nation that baldatun thoyyibatun wa rabbun ghaffur, a nation whose people love the savety, peace, and prosperity which of course is the dream of all humanity (Hasan 2015). University in Indonesia as an institution that carries the mandate to educate and produce graduates who are able to develop self-competence, mindset, attitude and act patterns that reflect themselves as intelligent 
individuals, have noble character and possess the necessary skills for themselves, society, nation and state (Act No. 20 2003), then its success is strongly influenced by the performance of the educators. While in the context of PTIS, Hasan (2015) said that one of the goals of Islamic Higher Education (PTI) is to produce graduates who have the intellectual and spiritual ability so as to build society and able to orient all their activities for the purpose of worshiping Allah SWT. This is in accordance with the basic doctrine of the purpose of human creation as described in QS. Dzariyat verse 56 which means "And I did not create Jinn and Human except to worship Me". To achieve the goals of PTI, educator (lecturer) is required to understand and able to apply Islamic behavior in work, especially in the learning process to the learners, which later in the formulation of this research called the work ethic of Islam. Besides, how an organization is able to generate and sustain the performance of its members in the long term, Bourdieu (2011) said that "it is important for every individual to have social capital to facilitate the achievement of performance as it has been charged to him". While other experts also said that the commitment of an employee to the institution is also a factor that must be owned by every member of the organization, because commitment to the organization is believed to be a driver for individuals to be serious in working so as to meet the performance targets charged to her/him. (Meyer, Stanley, Herscovitch, \& Topolnytsky, 2002; Yousef, 2001).

\subsection{Research Problem}

Based on the above reasoning, researcher need to investigate the effect of Islamic Work Ethics Moderation on Social Capital, Organizational Commitment, and Lecturer Performance.

\subsection{Research Purpose}

This research purpose is to understand and explore the effect of Islamic Work Ethics Moderation on Social Capital, Organizational Commitment, and Lecturer Performance.

\section{THEORETICAL FRAMEWORK AND HYPHOTESES DEVELOPMENT}

\subsection{Theoretical Framework}

\subsubsection{Islamic Work Ethics}

The work ethic is basic belief in which a person should perform work by applying fundamental values and that everyone should do so in the best possible way, regardless the reward (Stackhouse, 1995). Meanwhile, Cherrington (1980) defines the Work Ethic as a cultural norm that makes a person trustworthy and responsible for a job that she/he does, based on a belief that the work has an intrinsic value to his personality. From the description, it can be concluded that the work ethic is the beliefs or fundamental principles that serve as a guideline for a person in doing work activities. Working in Islam occupies a very noble position. Islam highly appreciates the people who work. Even Islam believes that when a person feels exhausted after going home to work, then Allah SWT forgive her/his sins right that moment. Ibn Abbas ra said which means: "I heard the Prophet Muhammad SAW said, Those who feel fatigue in the afternoon, because of work done by both hands, then her/his sins are forgiven by Allah SWT on that afternoon." (Narrated by Imam Tabrani, in Al-Mu'jam Al-Ausath VII / 289.). In another hadith, it is said that by working Allah will remove the sins of man that cannot be removed with the reward of prayer, fasting, pilgrimage and umroh. From Abu Hurairah ra said that Rasulullah SAW said that "among the sins there is a sin that cannot be forgiven with prayer, fasting, hajj and also umrah." The Companion asked, "What can erase it, O Messenger of Allah?" He replied, "The spirit in seeking rizki (work)". (HR Thabrani, in Al-Mu'jam Al-Ausath I / 38). Meanwhile, working in the view of Islam is a very noble act, because by working Muslims are considered to have maintained their dignity and human dignity (Suprayogo, 2012). Thus Islam gives a very high appreciation for those who want to try hard to work in earnings money (income). Therefore Islam categorizes work as worship, as commanded by Allah SWT in (Surat At Taubah 105) which means "And say, do (as you will), for Allah will see your deeds and (so will) His messenger and the believers. And you will be returned to 
the Knower of the unseen and the witnessed, and He will inform you of what you used to do." The ethics of work in the Islamic context, based on Islamic teachings derived from the Qur'an and AlHadith (Ali \& Al-Owaihan, 2008; Kamaluddin \& Manan, 2010; Owoyemi, 2012) as described above. Basically, Islamic Work Ethics giving guidance to every Muslim in her/his life, especially related to work. Some dimensions related to Islamic work ethics provide guidance nature of intentions (motivation) in work, choosing work, behavior in work, and attitude in receiving the work result; (Commentary of the Qur'an Thematic, 2010). In this study, indicators used to analyze the ethics of Islamic work include the intention (motivation) in work, sincere in working, can be trusted, trustworthiness (towards the work result and left it to God), istiqomah (consistent in work, consistent between beliefs of heart, oral, and action), itqon (professional in work), and qonaah (always felt enough).

\subsubsection{Organizational Commitment}

Mowday, Porter, \& Steers (2013) defines Organizational Commitment as the power of individual identification within an organization through a strong desire to become a member of the best organization by involving oneself wholeheartedly and pursue work, which is based on acceptance of organizational values and goals. So, it can be concluded that organizational commitment is an attitude of ownership, involvement, responsibility, high employee loyalty to the organization. Curtis \& Wright (2001) describe the dimensions of organizational commitment into three elements, namely: (1) the desire to maintain membership in the organization; (2) Confidence and acceptance of the organization's values and objectives; and (3) Willingness to work hard as part of the organization. In general, Zurnali (2010) said that research related to employees with strong affective commitment will remain with the organization because they want to stay tied and loyal both emotionally and psychologically to the organization. While employees are said to have a strong commitment continuance because they feel they must (because they have to) live with the organization and remain part of the organization on the basis of consideration of profit and loss. And employees are said to have a strong normative commitment because they feel they have to live together because of the reflection of responsibility feeling to remain part of the organization. Meyer \& Allen (1991), Meyer, Stanley, Herscovitch, \& Topolnytsky (2002) states that organizational commitment as a "good" psychological state, characterizes the relationship of the affected organization to influence what the employee continues to be with the organization. "It can be identified through three components: (1) Affective commitment, ie, one's emotional involvement in the organization (2) Continuance commitment, which is a person's perceptions of costs and risks by leaving the organization today. Which means, there are two aspects on the organization Continuous commitment, ie: involves personal sacrifice if leaving the organization and the absence of alternatives available to the person, with indicators, by taking into account the benefits of staying in the organization and the disadvantages of leaving the organization. 3) Normative commitment: a moral dimension based on responsible feelings, with indicators such as the willingness to work and responsibility to advance the organization. Measurement of Organizational Commitment in this study is based on indicators developed by (Mowday, Steers, \& Porter, 1979), namely (1) the desire to maintain membership in the organization; (2) conformity with organizational values and objectives; and (3) Seriousness in work.

\subsubsection{Social Capital}

The definition of social capital put forward by experts is strongly influenced by the object/subject in her/his research. This affects the diverse understanding of the concept of social capital. Putnam (1993) states that social capital as a characteristic that exists in a social organization or society such as trust, applicable norm and networks owned, so she/he concludes that in order to become a strong organization, the organization must build trust, create mutually agreed and shared norms, and build a broad network. Meanwhile, Lin (2008) said that social capital is a diverse range of resources within the social network, accessible and transferable by both parties within the 
organization through ties in social networks. Social capital is transmitted through cultural mechanisms such as religion, tradition, or historical habits (Fukuyama 2001). Social capital is needed to create a kind of moral community that can not be obtained as in the case of human capital forms. The acquisition of social capital requires the habitualization of the moral norms of a community and in its context as well as the adoption of virtues. Dasgupta \& Serageldin (2001) believe social capital is something that refers to the institutional dimension, the relationships created, and the norms that shape the quality and quantity of social relationships in society. Social capital is not just a row of the number of institutions or groups that underpinning social life, but with a broader spectrum. That is as a glue or social glue that keep the unity of group members together. Some references to values and elements that constitute the spirit of social capital include : participatory attitudes, mutual attitudes, mutual giving and receiving, trusting each other trusting and reinforced by the values and norms that support it. Another element that plays an important role is the willingness of society to continuously proactive both in maintaining value, forming cooperation network and with the making of new creations and ideas. This is the true identity of social capital. Individual social capital study conducted by Bourdieu (2011), which states that social capital as the total number of resources owned by individuals/groups as a result of networking. The emphasis of social capital in the concept focuses on one's relationships with others, the orientation for the achievement of individual goals and the power of social capital lies in the control of each individual. Discussion of social capital in the educational context, Mohammad (2012) said that the wider social network of an educator, the higher opportunity to exchange knowledge, technology, expertise, and other benefits, and the higher opportunity to improve performance. In addition, educator that has more network is easier to get support from co-workers than those who do not have networks, and has better performing chances. In this study social capital is meant to be the individual social capital, characterized by networking in and out of the organization (Network), Trustworthiness (Trust), and the similarity of vision, mission, and goals (share goal).

\subsubsection{Performance}

Koopmans, Bernaards, Hildebrandt, Schaufeli, de Vet Henrica, \& van der Beek (2011) defines individual performance as recording results obtained from functions of a particular job or activity over a period of time. According to behavioral approach in management, performance is the quantity or quality of something produced or services provided by a person doing the work (Luthans, 2010). While Mathis \& Jackson (2006) state that performance is basically what employees do or not do. Factors that affect performance by Mathis \& Jackson (2006):

a. Effectiveness and efficiency. When a certain goal is finally achieved, we may say that the activity is effective but if the consequences of the activity that are not sought to assess the importance of the results achieved so as to result in satisfaction although effectively is called inefficient. Conversely, if the consequences are sought is not important or trivial then the activity is efficient.

b. Authority. Authority is the nature of a communication or command in a formal organization that belongs to an organization member to other members to perform a work activity in accordance with its contribution. The order says what is allowed and what not allowed in the organization.

c. Discipline. Discipline is obedient to applicable laws and regulations. Thus, employee's discipline is the activity of the employeke concerned in respecting employment agreement with the organization where she/he works.

d. Initiative. The initiative is related to the power of thought and creativity in shaping the idea to plan something related to organizational goals.

While what is related to employee performance indicators such as stated by Robbins (2006), there are six indicators to measure the performance of employee individually, namely:

1. Quality. Quality of work is measured by employee perceptions over the quality of work produced as well as the perfection of tasks to the skills and abilities of employees. 
2. Quantity. Represents amount generated and expressed in terms of number of units, number of completed activity cycles.

3. Timeliness. Represents activity level completed at the beginning of stated time, viewed from the point of coordination with the output and maximizing the time available for other activities.

4. Effectiveness. Represents the level of organizational resources usage (energy, money, technology, raw materials) maximized with intention to increase the yield of each unit in the use of resources.

5. Independence. Represents the level of employee which later will be able to perform her/his work function as Work commitment. It is also a level where employees have a working commitment with the agency and responsibility of employees to the office.

In the context of lecturer profession, performance is measured by taking into account the lecturer's workload and evaluation of 'tridharma' higher education implementation, including:

1. Education and Teaching Activities.

2. Research Activities.

3. Community Service Activities.

4. Supporting Activities.

\subsubsection{The Relationships Between Social Capital and Performance}

Technological progress as one of the globalization era characteristics requires a lecturer to further strengthen individual social capital in order to facilitate the exchange of information so that it is expected to improve its performance. The relation between social capital and performance are based on the theory of social resources, which represents a form of social support for individuals to solve the problems they are facing (Purba, Yulianto, Widyanti, Esa, 2007). As Lin (2008) noted, in social networks there are various social resources (information, support, trust) that can benefit all members of the network for social support. Thus, a lecturer will get social support to improve his performance, if she/he is able to access the existing resources in his social network, then it will become social capital for the individual (Mohammad, 2012). Several studies have shown that individual social capital has a positive effect on performance (Ferdinand, 2005; Abbasi, Hossain, \& Wigand, 2011; Seibert, Kraimer, \& Liden, 2001). Based on the results of the research, the first hypothesis is arranged as follows:

\section{$\mathrm{H}_{1}$ : Individual Social Capital Affects Performance}

\subsubsection{The Relationships Between Organizational Commitment and Performance}

Someone who has an organizational commitment can be seen from his seriousness in working as an effort to give maximum contribution for the development of the organization. The sincerity in working is a manifestation of the person's acceptance and conformity to the vision, mission and objectives set by the organization and her/his desire to remain a member of the organization (Mowday, Porter, \& Steers, 2013). Thus, the higher a person's commitment to the organization in which he is joined in, the higher her/his performance is. Several previous studies have shown that organizational commitment contributes positively to one's performance (Becker, Billings, Eveleth, \& Gilbert, 1996; Khan, Ziauddin, \& Ramay, 2010; de Araújo \& Lopes 2014). Thus hypothesis 2 is structured as follows:

$\mathrm{H}_{2}$ : Organizational Commitment has a positive effect on lecturer performance.

\subsubsection{Islamic Work Ethics as Moderating Role}

The influence of social capital influence and organizational commitment to lecturer performance will be more effective and stronger influence if supported by ethical behavior owned by lecturer. Ethical behavior as the guiding principles in work will have a positive effect on the establishment of a comfortable working atmosphere, because each work is based on good moral principles. Ethical behavior will create an atmosphere of togetherness that brings cohesiveness to 
members of the organization so that harmonization of relationships between individuals involved in the organization will be occured. A comfortable working atmosphere and togetherness will enhance cooperation between individuals, resulting in increased employee productivity. In this study, the ethical behavior is the ethical work of Islam. Thus the third and fourth hypotheses are structured as follows:

\section{$\mathrm{H}_{3}$ : Islamic work ethics reinforces the influence of social capital on the performance of lecturers}

$\mathrm{H}_{4}$ : Islamic work ethics reinforces the influence of organizational commitment to lecturer performance

\section{RESEARCH METHOD}

\subsection{Research Design}

This research can be classify as quantitave research with descriptive and (survey) questionnaire as the research tools. A survey questionnaire comprising of demographic information and measures of the research variables. While descriptive analysis is used to give researcher a broader insight related respondent profile based on the answers of statements in the questionnaire. Data analysis in this study done by using WarpPls 5.

\subsection{Population and Sample}

The population in this study is lecturers of Islamic Private Universities (PTIS) in Indonesia who have an A institution accreditation, with the criteria of permanent lecturer of foundation/association or lecturer of Civil Servant (PNS) attributed to the PTIS, and has the lowest functional position as expert assistant. With these criteria, number of population in this study amounted to 1711 lecturers. By using Slovin formula at $7.5 \%$ error, 162 samples of people are obtained. A total of 600 questionnaires were distributed in random sampling and returned as many as 254 copies. Of these, 236 copies fulfilled the requirements.

\subsection{Research Variables}

Islamic work ethics is measured on the basis of intention (motivation) in work, choosing work, behavior in work, and attitude in receiving the work; (Thematic Qur'an Commentary, 2010). In this study the indicators used to analyze the ethics of Islamic work include the intention (motivation) in work, sincere in work, trustworthy, surrender towards the work (left it to God), istiqomah (consistent in work, consistent between beliefs of the heart, oral, and action), itqon (professional in work), and qonaah (always felt enough). Measurement scale using scale 1-5 likert, (1 for answers strongly disagree, 5 answers to strongly agree). Organizational commitment is measured by indicators developed (Mowday, Steers, \& Porter, 1979), in which organizational commitment is characterized by acceptance of organizational goals, sincerity in trying for the sake of organization, and the desire to stay in organization. Measurement scale using scale 1-5 likert, (1 strongly disagree, 5 - strongly agree). Social Capital is measured based on indicators developed by Lin (2008), including networking, relationships based on mutual trust, and the existence of the same goal/share goal between individuals in one lecturer community. Measurement scale using scale 1-5 likert, ( 1 for answer strongly disagree, 5 answers to strongly agree). Performance is measured by Indonesian government regulations related to lecturers workload (Act No. 12 2012), known as tri dharma principle which is consist of education performance (teaching aspects), research performance, community service performance, and other supporting performance. This variables is measures by using 1 and 0 Gutman scale, ( 1 for Yes answer, 0 for No answer). In questionnaire validity test with Guttman scale, reproducibility and scalability coefficient test developed by DunnRankin, Knezek, Wallace, \& Zhang, (2014) is used which stipulates that reproducibility coefficient value should be $>0.90$ and scalability coefficient value should be $>0.6$. Based on the test, reproducibility coefficient of performance questionnaire in this study amounted to 0.912 and scalability coefficient amounted to 0.761 . 


\subsection{Research Framework}

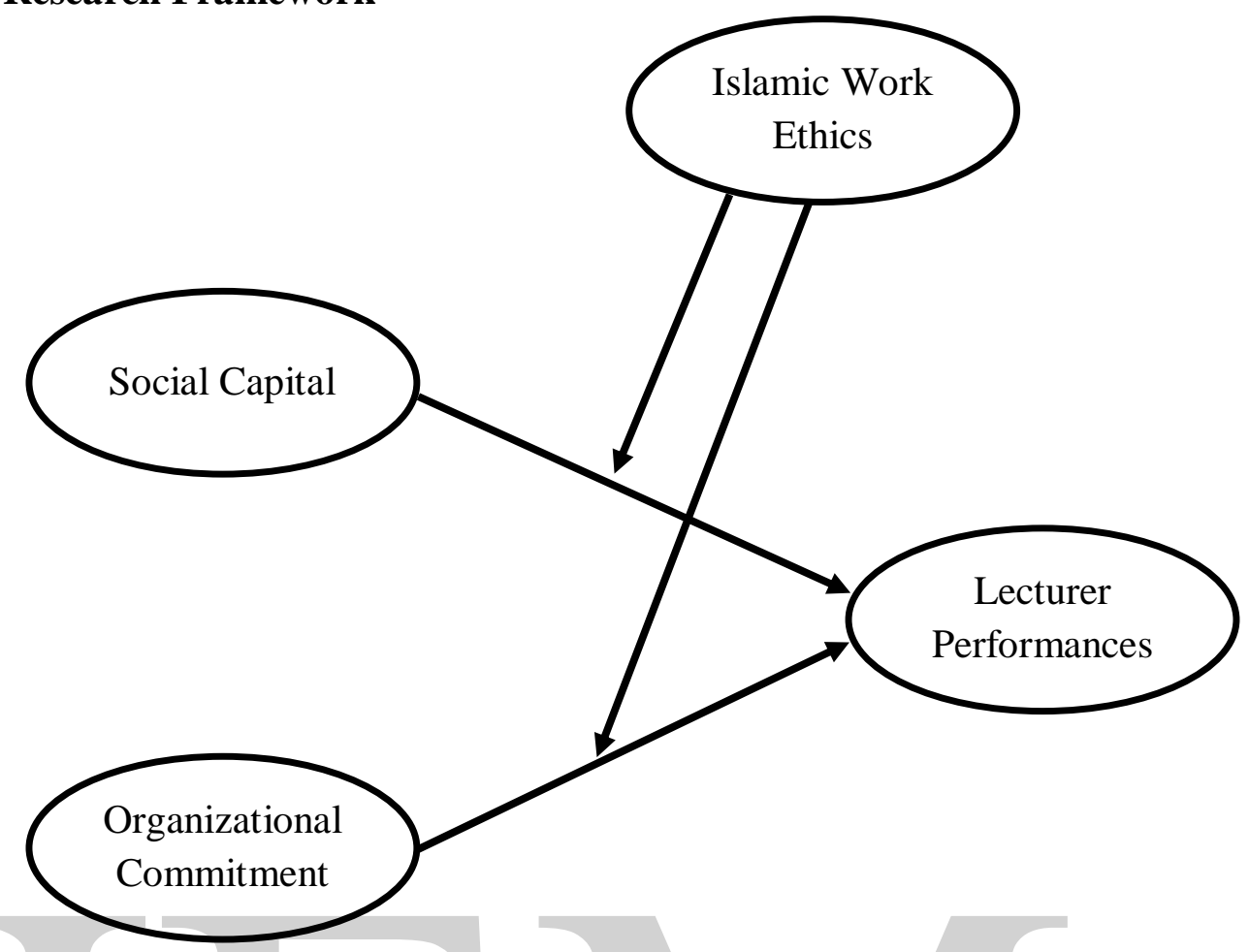

Picture 1 Research Framework

\section{RESEARCH RESULT AND ANALYSIS}

\subsection{Descriptive Analysis}

Table 1 Respondent Characteristics

\begin{tabular}{|c|r|c|}
\hline Respondent Characteristic & Total & Percentage \\
\hline Age & & \\
\hline$<40$ & 87 & $37 \%$ \\
\hline $40-60$ & 144 & $61 \%$ \\
\hline$>60$ & 5 & $2 \%$ \\
\hline Level of Education & & \\
\hline Magister & 179 & $76 \%$ \\
\hline Doctoral & 57 & $24 \%$ \\
\hline Work Experiences (Year) & & \\
\hline $3-10$ & 76 & $32 \%$ \\
\hline $11-20$ & 70 & $30 \%$ \\
\hline $21-30$ & 85 & $36 \%$ \\
\hline$>30$ & 5 & $2 \%$ \\
\hline Lecturer Level & & \\
\hline Associate Lecture & 92 & $39 \%$ \\
\hline Assistant Professor & 64 & $27 \%$ \\
\hline Associate Professor & 78 & $33 \%$ \\
\hline Professor & 2 & $1 \%$ \\
\hline
\end{tabular}




\subsection{Validity and Reliability}

Outer model is used to measure reliability and validity of formative indicators of latent variable. While reflective indicators is measured by loading factor, composite reliability, avarage variance extracted, and discriminant validity.

Table 2 Loading Factor

\begin{tabular}{|l|l|l|l|l|}
\hline \multirow{4}{*}{ Variable } & Indicator & Loading Factor & Type of Indicator & P value \\
\hline \multirow{4}{*}{ Social Capital } & MS-1 & 0.792 & Reflect & $<0.001$ \\
\cline { 2 - 5 } & MS-2 & 0.857 & Reflect & $<0.001$ \\
\cline { 2 - 5 } & MS-3 & 0.868 & Reflect & $<0.001$ \\
\hline \multirow{5}{*}{ Organizational Commitment } & KO-1 & 0.838 & Reflect & $<0.001$ \\
\cline { 2 - 5 } & KO-2 & 0.890 & Reflect & $<0.001$ \\
\cline { 2 - 5 } & KO-3 & 0.330 & Reflect & $<0.001$ \\
\hline \multirow{5}{*}{ Islamic Work Ethics } & EKI-1 & 0.552 & Reflect & $<0.001$ \\
\cline { 2 - 5 } & EKI-2 & 0.758 & Reflect & $<0.001$ \\
\cline { 2 - 5 } & EKI-3 & 0.410 & Reflect & $<0.001$ \\
\cline { 2 - 5 } & EKI-4 & 0.799 & Reflect & $<0.001$ \\
\cline { 2 - 5 } & EKI-5 & 0.773 & Reflect & $<0.001$ \\
\cline { 2 - 5 } & EKI-6 & 0.553 & Reflect & $<0.001$ \\
\cline { 2 - 5 } & EKI-7 & 0.585 & Reflect & $<0.001$ \\
\hline
\end{tabular}

Variables with formative indicators can be seen as reliable variable if P-value $<0.05$ and VIF $<3.3$ (Kock, 2015). As for the internal consistency reliability shown by the composite reliability values of each variable are capital social variable is 0.877 , organizational commitment variable is 0.752 , Islamic work ethic variable is 0.828 and performance variable is 0.829 . Variables meet the criteria of composite reliability if the value is more than 0.7. (Hair, 2010). Furthermore, Average variance Extracted (AVE) is used to know how far the research indicator is able to explain variable. The recommended values is AVE > 0.50; (Fornell \& Larcker, 1981). Based on the analysis, it can be conclude that the AVE of the four variables are meet the prescribed prerequisites because the value is more than $0.59,0.705$ for social capital variable, 0,534 for organizational commitment variable, 0,519 for Islamic work ethic variable and 0.551 for lecturer's performance variable.

For reflective indicators, there is one more criteria which is discriminant validity (the square root of AVE of each construct must be greater than the correlation between constructs in the model) that must be meets to see if the construct are reliabile or valid of the construct.

Table 3 Correlations Among 1. vs. with sq. rts. of AVEs

\begin{tabular}{|l|c|r|r|r|}
\hline Variable & $\begin{array}{c}\text { Social } \\
\text { Capital }\end{array}$ & $\begin{array}{c}\text { Organizational } \\
\text { Commitment }\end{array}$ & $\begin{array}{c}\text { Islamic Work } \\
\text { Ethics }\end{array}$ & $\begin{array}{c}\text { Lecturer } \\
\text { Performance }\end{array}$ \\
\hline Social Capital & 0.840 & 0.501 & 0.506 & 0.363 \\
\hline Organizational Commitment & 0.501 & 0.731 & 0.491 & 0.496 \\
\hline Islamic Work Ethics & 0.506 & 0.491 & 0.647 & 0.412 \\
\hline Lecturer Performance & 0.363 & 0.496 & 0.412 & 0.742 \\
\hline
\end{tabular}

Based on table 3, it can be concluded that all constructs with reflective indicators have met the criteria of discriminant validity. The construct validity and reliability with formative indicators, determined by the indicator of weights and VIF value. The terms are P-value $<0,05$ and VIF $<3.3$; (Kock, 2015). 
Table 4 Weight Indicators

\begin{tabular}{|c|l|l|l|c|c|}
\hline Variable & Indicator & Weight Indicator & Type of Indicator & P value & VIF \\
\hline \multirow{4}{*}{$\begin{array}{c}\text { Lecturer } \\
\text { Performance }\end{array}$} & KD-1 & 0.343 & Formative & $<0.001$ & 1.823 \\
\cline { 2 - 6 } & KD-2 & 0.289 & Formative & $<0.001$ & 1.153 \\
\cline { 2 - 6 } & KD-3 & 0.351 & Formative & $<0.001$ & 1.725 \\
\cline { 2 - 6 } & KD-4 & 0.360 & Formative & $<0.001$ & 1.419 \\
\hline
\end{tabular}

\subsection{Research Analysis}

Evaluation of Structural Model (inner model) is used to predict the relationship between latent variables by looking at how much variance can be explained and to know the significance of PValue. Some items that need attention include the R-square of each endogenous latent variable to find out the predictive power of the structural model. The Stone-Geisher test to test predictive relevance, and the goodness of fit $(\mathrm{GoF})$ is to measure the strength of the model as a whole. Based on the result, we can see that the model has a good fit because the P-value for Average Path Coefficient (APC) is 0.321, Average R-Squared (ARS) is 0.273, and Average Adjusted R-squared (AARS) is 0.257. Average block of VIF (AVIF) and Average Full Collinearity of VIF (AFVIF) that produced in this research is more than 3.3. Therefore, it can be concluded that there is no multicollinearity between indicators and latent variables. The value of Tenenhaus GoF (GoF) is 0.272 (> 0.25) which means that the model has moderate strength. Sympson's paradox ratio (SPR), R-squared contribution ratio (RSCR), Statistical suppression ratio (SSR), and Nonlinear bivariate causality direction ratio (NLBCDR) generated above all conditions. This indicates that there is no causality problem in the model and iteration for this model is done 7 times.
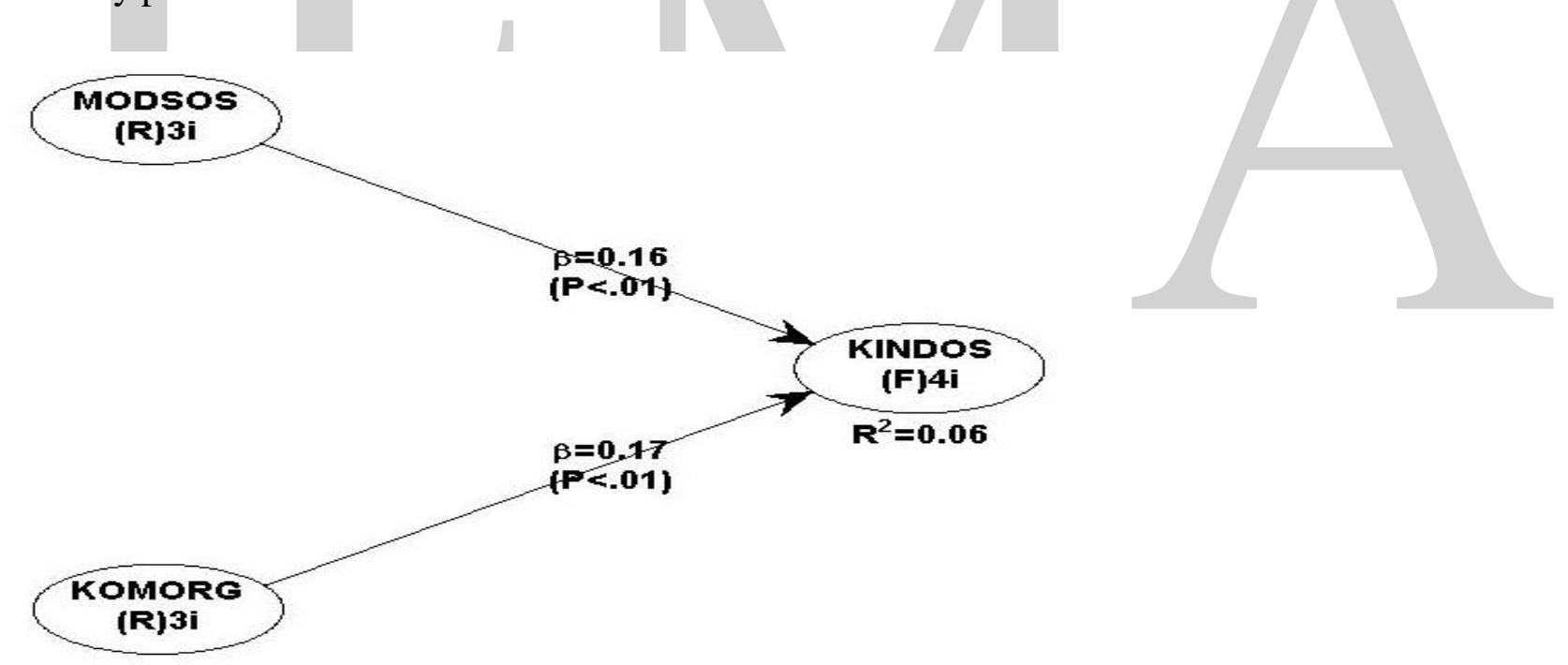

Picture 2 Before Moderation 


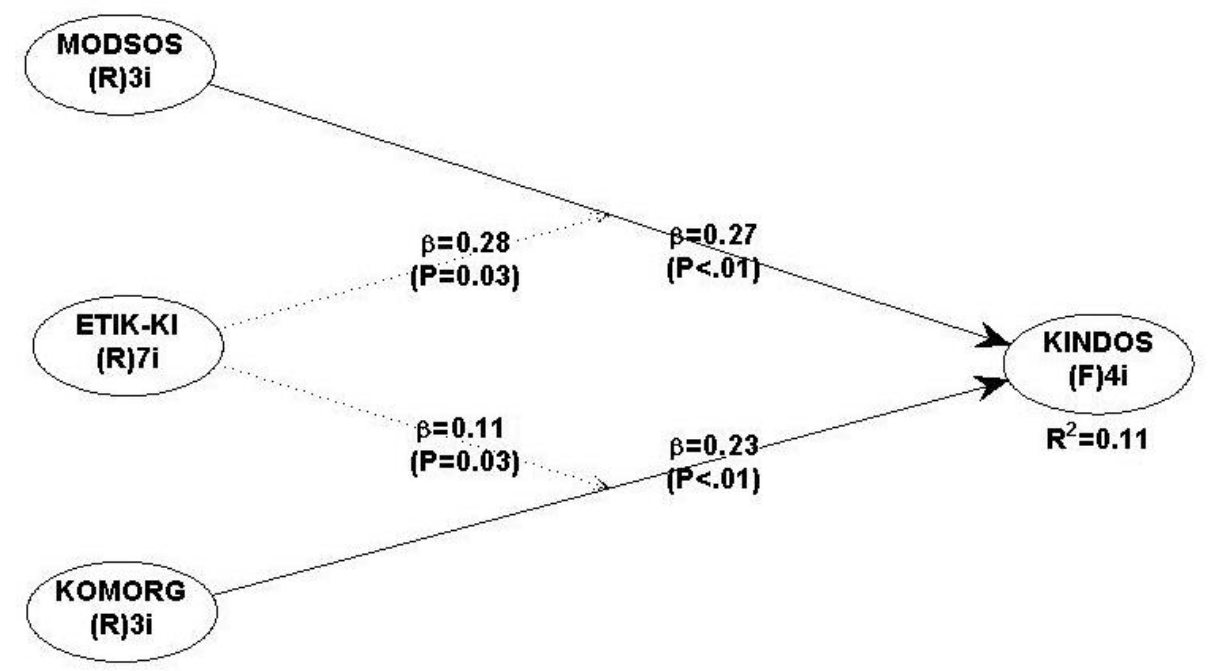

Picture 3 After Moderation

Picture 2 is the result of data analysis before including Islamic work ethic variable as a moderation variable. Picture 2 shows that the percentage of variance (R2) in the endogenous latent variable is $6 \%$. Social capital has a positive influence on lecturers performance with path coefficient amounted to $\beta=0,16$ and probability $\operatorname{Pof}<0,001$. Otherwise, organizational commitment has a positive effect on lecturer performance with $\beta=0.17$ and probability $\mathrm{P}$ of $<0.001$. Picture 3 is the analysis result after inserted Islamic work ethic as a moderation variable. Its increased the percentage of variance $\mathrm{R}^{2}$ to $11 \%$.

Table 5 Path Coefficients

\begin{tabular}{|l|l|l|l|l|l|l|}
\hline Variable & MODSOS & KOMORG & KINDOS & ETIK-KI & ETIK-KI & ETIK-KI \\
\hline MODSOS & & & & & & \\
\hline KOMORG & & & & & & \\
\hline KINDOS & 0.268 & 0.233 & & & 0.278 & 0.106 \\
\hline ETIK-KI & & & & & & \\
\hline ETIK-KI & & & & & & \\
\hline ETIK-KI & & & & & & \\
\hline
\end{tabular}

Table $6 \mathrm{P}$ values

\begin{tabular}{|l|l|l|l|l|l|l|}
\hline Variable & MODSOS & KOMORG & KINDOS & ETIK-KI & ETIK-KI & ETIK-KI \\
\hline MODSOS & & & & & & \\
\hline KOMORG & & & & & & \\
\hline KINDOS & $<0.001$ & $<0.001$ & & & 0.030 & 0.026 \\
\hline ETIK-KI & & & & & & \\
\hline ETIK-KI & & & & & & \\
\hline ETIK-KI & & & & & & \\
\hline
\end{tabular}

The result of path analysis and probability value $(\mathrm{P})$ after inserted of Islamic work ethic as moderation variable can be seen in Table 5 and 6 . Based on the data, it can be seen that social capital have positive effect on lecturer performance $(\beta=0,268 ; \mathrm{P}<0,001)$. Hence, hypothesis 1 which states Islamic work ethic has a positive influence on lecturer performance, is acceptable. This research also concluded that organizational commitment has an effect the performance of lecturers ( $\beta=0.233, \mathrm{P}<0.001)$, therefore hypothesis 2 is also stated accepted. The results also shows that 
Islamic work ethics moderate the influence of social capital on lecturer performance $(\beta=0,278 ; \mathrm{P}=$ $0,030)$. Islamic Work Ethics also moderates the influence of organizational commitment on lecturer performance $(\beta=0.106 ; \mathrm{P}=0.026)$. Thus hypotheses 3 and 4 is acceptable.

The result of data analysis shows that the overall hypothesis developed in this study is accepted. The social capital has a positive and significant impact on the lecturer's performance. In line with previous studies, at the individual social capital level characterized by mutual trust, the broad of network and the existence of same goal/share goal in respondent's environment has significantly improved its performance. It also provides information regarding social support theory, respondents get social support from their social networks because they have the ability to access all the resources (information, support, and trust) that exist within the network. Organizational commitment has a positive and significant impact on lecturer performance. It provides information about how important the present of common goal between individual lecturers and the institutions objectives, so that each lecturer motivated to work hard in realizing the tridharma of higher education, devoting all potential she/he has to achieving the organization's goals and continuously arising the desire to remain survives as a member of the institution. The Islamic work ethic moderates the influence of social capital and organizational commitment to the performance of lecturers. The research findings show that ethical behavior such as sincere, trustworthiness, can be trust (amanah), istiqomah, itqon, and qonaah based on the intention of work which only intended to worship Allah SWT, has a positive impact for the strengthening of lecturer's social capital through the strengthening of trust and network (network) and attitude of lecturer's commitment to the institution so that it impact on individual performance. It means that ethical behavior developed based on religious beliefs as well as the Islamic work ethic becomes appropriate if it is used as working principles which are used as work guidelines, especially in PTIS environment.

\section{RESEARCH CONCLUSION AND LIMITATION}

\subsection{Conclusion}

Based on data analysis results, it can be concluded that social capital and organizational commitment has a positive and significant impact on the performance of lecturers, as well as Islamic work ethic that strengthen the influence of social capital and organizational commitment to lecturer performance. Theoretically, the results of this study strengthen and expand the results of previous research. While on a practical level, the results of this study can be used as a basis of policy to encourage lecturers to strengthen their commitment for their institutions and strengthen social capital to gain social support through the development and strengthening of ethical behavior among lecturers based on religious (Islam) beliefs in order to improve its performance. The establishment of an ethical institution that oversees the performance behavior should be established to ensure the implementation of ethical behavior among the lecturers.

\subsection{Limitation}

This research only uses three variables (social capital, organizational commitment, and the moderating role of Islamic work ethics) to examine the performance of lecturer, therefore for future researchers who will conduct research on the same topic should use different variables. To strengthen the generalization of the research results in the responden group (PTIS lecturers' environment), a broader scope of research, including PTIS which has B and C accreditation, and even unaccredited PTIS need to be conducted. 


\section{REFERENCES}

Abbasi, A., Hossain, L., \& Wigand, R. (2011). Social capital and individual performance: a study of academic collaboration. arXiv preprint arXiv:1112.2460.

Abbasi, A. S., Mir, G. M., \& Hussain, M. (2012). Islamic Work Ethics: How it Affects Organizational Learning, Innovation and Performance. Actual Problems of Economics (12), 138.

Ali, A. J., \& Al-Owaihan, A. (2008). Islamic work ethic: a critical review. Cross cultural management: An international Journal 15 (1), 5-19.

Becker, T. E., Billings, R. S., Eveleth, D. M., \& Gilbert, N. L. (1996). Foci and bases of employee commitment: Implications for job performance. Academy of management journal 39 (2), 464-482.

Bourdieu, P. (2011). The forms of capital.(1986). Cultural theory: An anthology 1, 81-93.

Bozkurt, V., Bayram, N., Furnham, A., \& Dawes, G. (2010). The protestant work ethic and hedonism among Kyrgyz, Turkish and Australian college students. Drustvena Istrazivanja: Journal for General Social Issues 19 (4-5), 749-769.

Braun, S., Peus, C., Weisweiler, S., \& Frey, D. (2013). Transformational leadership, job satisfaction, and team performance: A multilevel mediation model of trust. The Leadership Quarterly 24(1), 270-283.

Chen, X.-P., Eberly, M. B., Chiang, T.-J., Farh, J.-L., \& Cheng, B.-S. (2014). Affective trust in Chinese leaders: Linking paternalistic leadership to employee performance. Journal of management 40(3),796-819.

Cherrington, D. J. 1980. The work ethic: Working values and values that work: Amacom.

Cho, S., \& Johanson, M. M. (2008). Organizational citizenship behavior and employee performance: A moderating effect of work status in restaurant employees. Journal of Hospitality \& Tourism Research 32(3), 307-326.

Curtis, S., \& Wright, D. (2001). Retaining employees-the fast track to commitment. Management Research News 24 (8/9), 59-64.

Dasgupta, P., \& Serageldin, I. (2001). Social capital: a multifaceted perspective: World Bank Publications.

de Araújo, M. S. G., \& Lopes, P. M. P. R. (2014). Virtuous leadership, organizational commitment and individual performance. Tékhne 12, Supplement 1:3-10.

Dessler, G. (2009). Manajemen Sumber Daya Manusia Jilid 2-10/E.

Dunn-Rankin, P., Knezek, G. A., Wallace, S. R., \& Zhang, S. (2014). Scaling methods: Psychology Press.

Ferdinand, A. T. (2005). Modal Sosial Dan Keunggulan Bersaing: Wajah Sosial Strategi Pemasaran.

Fornell, C., \& Larcker, D. F. (1981). Evaluating structural equation models with unobservable variables and measurement error. Journal of marketing research, 39-50. 
Fukuyama, F. (2001). Social capital, civil society and development. Third world quarterly 22 (1), 720.

Güngör, P. (2011). The relationship between reward management system and employee performance with the mediating role of motivation: A quantitative study on global banks. Procedia-Social and Behavioral Sciences 24, 1510-1520.

Hair, J. F. (2010). Multivariate data analysis, 7th Edition, Upper Saddle River, New Jersey, Pearson Education.

Harwiki, W. (2016). The Impact of Servant Leadership on Organization Culture, Organizational Commitment, Organizational Citizenship Behaviour (OCB) and Employee Performance in Women Cooperatives. Procedia-Social and Behavioral Sciences 219, 283-290.

Hasan, T. (2015). Dinamika Pemikiran tentang Pendidikan Islam. edited by C. Kedua: Lantabora Press : Jakarta-Indonesia

Hayati, K., \& Caniago, I. (2012). Islamic work ethic: The role of intrinsic motivation, job satisfaction, organizational commitment and job performance. Procedia-Social and Behavioral Sciences 65, 272-277.

Huey Yiing, L., \& Zaman Bin Ahmad, K. (2009). The moderating effects of organizational culture on the relationships between leadership behaviour and organizational commitment and between organizational commitment and job satisfaction and performance. Leadership \& Organization Development Journal 30 (1), 53-86.

Imam, A., Abbasi, A. S., \& Muneer, S. (2013). The impact of Islamic work ethics on employee performance: testing two models of personality $\mathrm{X}$ and personality Y. Science International (Lahore) 25 (3), 611-617.

Jaramillo, F., Mulki, J. P., \& Marshall, G. W. (2005). A meta-analysis of the relationship between organizational commitment and salesperson job performance: 25 years of research. Journal of Business Research 58 (6), 705-714.

Kamaluddin, N., \& Manan, S. K. A. (2010). The conceptual framework of Islamic work ethic (IWE). Malaysian Accounting Review 9 (2), 57-70.

Khan, M. R., Ziauddin, J. F., \& Ramay, M. (2010). The impacts of organizational commitment on employee job performance. European Journal of Social Sciences 15 (3), 292-298.

Kock, N. (2015). WarpPLS 5.0 User Manual. Laredo, TX: ScriptWarp Systems, Texas, USA.

Koopmans, L., Bernaards, C. M., Hildebrandt, V. H., Schaufeli, W. B., de Vet Henrica, C. \& van der Beek, A. J. (2011). Conceptual frameworks of individual work performance: a systematic review. Journal of Occupational and Environmental Medicine 53 (8), 856-866.

Lin, N. (2008). A network theory of social capital, in D. Castiglione, J.W. Van Deth .. Handbook of Social Capital, New York: Oxford University Press, pp.50-69.

Luthans, F. (2010). Organizational behavior: An evidence-based approach: McGraw-Hill Irwin.

Mathis, R. L., \& Jackson, J. H. (2006). Human Resource Management: Manajemen Sumber Daya Manusia Edisi Kesepuluh: Penerjemah: Diana Angelica. Jakarta: Salemba Empat. 
Memari, N., Mahdieh, O., \& Marnani, A. B. (2013). The impact of Organizational Commitment on Employees Job Performance." A study of Meli bank". Interdisciplinary Journal of Contemporary Research In Business 5 (5), 164.

Meyer, J. P., \& Allen, N. J. (1991). A three-component conceptualization of organizational commitment. Human resource management review 1 (1), 61-89.

Meyer, J. P., Paunonen, S. V., Gellatly, I. R., Goffin, R. D., \& Jackson, D. N. (1989). Organizational commitment and job performance: It's the nature of the commitment that counts. Journal of applied Psychology 74 (1), 152.

Meyer, J. P., Stanley, D. J., Herscovitch, L. \& Topolnytsky, L. (2002). Affective, continuance, and normative commitment to the organization: A meta-analysis of antecedents, correlates, and consequences. Journal of Vocational Behavior 61 (1), 20-52.

Mohammad, F. (2012). PENINGKATAN KINERJA DOSEN BERBASIS MODAL SOSIAL DAN DUKUNGAN ORGANISASIONAL DI PTS KOTA SEMARANG. Jurnal Bisnis dan Ekonomi 19 (2).

Mowday, R. T., Porter, L. W., \& Steers, R. M. (2013). Employee-organization linkages: The psychology of commitment, absenteeism, and turnover: Academic Press.

Mowday, R. T., Steers, R. M., \& Porter, L. W. (1979). The measurement of organizational commitment. Journal of Vocational Behavior 14 (2), 224-247.

Owoyemi, M. Y. (2012). The concept of Islamic work ethic: An analysis of some salient points in the prophetic tradition. International Journal of Business and Social Science 3 (20).

Purba, J., Yulianto, A., Widyanti, E., Esa, D. F. P. U. I., \& Esa, M. F. P. U. I. (2007). Pengaruh dukungan sosial terhadap burnout pada guru. Jurnal Psikologi 5 (1), 77-87.

Putnam, R. D. (1993). The prosperous community: social capital and public life. The american prospect (13).

Robbins, S. (2006). Perilaku Organisasi, Edisi Kesepuluh. Jakarta: PT. Indeks, Kelompok Gramedia.

Seibert, S. E., Kraimer, M. L., \& Liden, R. C. (2001). A social capital theory of career success. Academy of management journal 44 (2), 219-237.

Stackhouse, M. L. (1995). On moral business: Classical and contemporary resources for ethics in economic life: Wm. B. Eerdmans Publishing.

Suprayogo, I. P. D. (2012). Spirit Islam Menuju Perubahan dan Kemajuan. Malang: UIN Maliki Press.

Walumbwa, F. O., Mayer, D. M., Wang, P., Wang, H., Workman, K. \& Christensen, A. L. (2011). Linking ethical leadership to employee performance: The roles of leader-member exchange, self-efficacy, and organizational identification. Organizational Behavior and Human Decision Processes 115 (2), 204-213.

Wong, C. A., \& Laschinger, H. K. (2013). Authentic leadership, performance, and job satisfaction: the mediating role of empowerment. Journal of advanced nursing 69 (4), 947-959. 
Jurnal Ilmiah Bidang Akuntansi dan Manajemen (JEMA) Vol. 15 No. 1 (2018)

http://riset.unisma.ac.id/index.php/jema (p-ISSN : 1693-7864, e-ISSN : 2597-4071)

Yousef, D. A. (2001). Islamic work ethic-A moderator between organizational commitment and job satisfaction in a cross-cultural context. Personnel Review 30 (2), 152-169.

Zurnali, C. (2010). Learning Organization, Competency, Organizational Commitment, dan Customer Orientation: Knowledge Worker-Kerangka Riset Manajemen Sumberdaya Manusia di Masa Depan. Bandung: Penerbit Unpad Press.

*) Pardiman, University of Islam Malang, Malang, Indonesia (E-Mail: pardiman@unisma.ac.id)

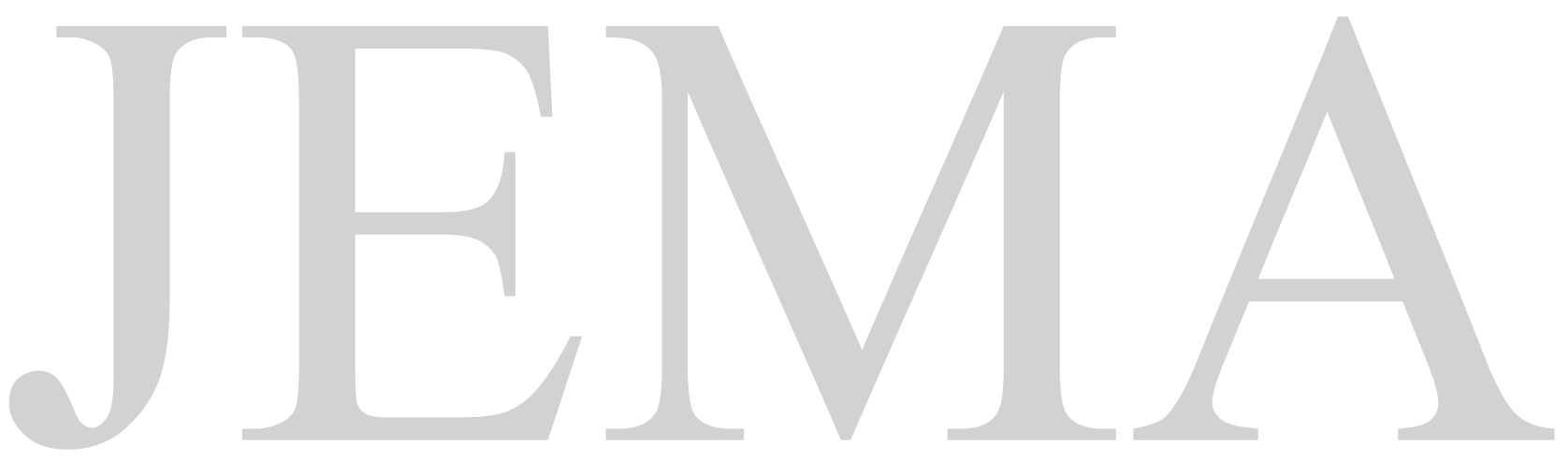

